\title{
Gynecologic and Obstetric Investigation
}

Founded 1895 as 'Monatsschrift für Geburtshilfe und Gynäkologie', continued 1946-1969 as 'Gynaecologia' and 1970-1977 as 'Gynecologic Investigation' Founders: A. Martin and M. Sänger

Former Editors: E. Anderes (1939-1952), Th. Koller (1939-1969), O. Käser (1954-1969), R. Wenner (1959-1967), P. Bloch (1965-1969), W.L. Hermann (1970-1975),

P.J. Keller (1976-1984), G. Zador (1985-2001), J. Yankowitz (2002-2005)

\section{Editor-in-Chief}

T.M. D’Hooghe, Leuven

\section{Associate Editors}

Biostatistics

Ariel A. Abad, Leuven

Clinical Obstetrics

Rohan D'Souza, Toronto, Ont.

Edgar Hernandez-Andrade,

Detroit, Mich.

\section{Contraception}

Antonio Cano, Valencia

Aileen Gariepy, New Haven, Conn.

Early Pregnancy and

Recurrent Miscarriage

Ole B. Christiansen, Copenhagen

Gynecologic Oncology

Christina Bandera, Cranston, R.I.

Viola Heinzelmann-Schwarz, Basel

David Mutch, St. Louis, Mo.

Gynecological Ultrasound and Imaging George Condous, St. Leonards, N.S.W. Eva Dreisler, Copenhagen

Infectious Diseases

Gilbert G.G. Donders, Leuven

Menopause

Lubna Pal, New Haven, Conn.
Prenatal Diagnosis and Therapy

Tim Van Mieghem, Toronto, Ont.

Psychology, Sexuology and

Mental Health

Jacky Boivin, Cardiff

Reproductive Biology

Joris Vriens, Leuven

Reproductive Endocrinology and Infertility

Thinus F. Kruger, Tygerberg

Reproductive Genetics

Zi-Jiang Chen, Jinan

Reproductive Immunology

Sun-Wei Guo, Shanghai

Reproductive Public Health

Aileen Gariepy, New Haven, Conn.

Society/Ethics/History

I. D. Cooke, Sheffield

Urogynecology

Jan-Paul Roovers, Amsterdam 
S. Karger

Medical and Scientific Publishers

Basel $\cdot$ Freiburg $\cdot$ Paris $\bullet$ London .

New York $\cdot$ Chennai $\cdot$ New Delhi $•$

Bangkok $\cdot$ Beijing $\cdot$ Shanghai $\cdot$ Tokyo $\cdot$

Kuala Lumpur $\cdot$ Singapore $\cdot$ Sydney

\section{Disclaimer}

The statements, opinions and data contained in this publication are solely those of the individual authors and contributors and not of the publisher and the editor(s). The appearance of advertisements in the journal is not a warranty, endorsement, or approval of the products or services advertised or of their effectiveness, quality or safety. The publisher and the editor(s) disclaim responsibility for any injury to persons or property resulting from any ideas, methods, instructions or products referred to in the content or advertisements.

Drug Dosage

The authors and the publisher have exerted every effort to ensure that drug selection and dosage set forth in this text are in accord with current recommendations and practice at the time of publication. However, in view of ongoing research, changes in government regulations, and the constant flow of information relating to drug therapy and drug reactions, the reader is urged to check the package insert for each drug for any change in indications and dosage and for added warnings and precautions. This is particularly important when the recommended agent is a new and/or infrequently employed drug.
All rights reserved

No part of this publication may be translated into other languages, reproduced or utilized in any form or by any means, electronic or mechanical, including photocopying, recording, microcopying, or by any information storage and retrieval system, without permission in writing from the publisher or in the case of photocopying, direct payment of a specified fee to the Copyright Clearance Center (see 'General Information')

(c) Copyright 2015/2016 by S. Karger AG,

CH-4009 Basel (Switzerland)

Printed on acid-free and non-aging paper (ISO 9706)

\section{KARGER}


Gynecologic and

Obstetric Investigation

No. 1

Original Articles

1 An Analysis of Prognostic Factors in Patients with Ovarian Malignant Germ Cell Tumors Who Are Treated with Fertility-Preserving Surgery

Yang, Z.; Liu, Z.; Wei, R.; Li, L. (Nanning)

10 Different Patterns of Disease Spread between Advanced-Stage Type I and II Epithelial Ovarian Cancer Bergamini, A.; Candiani, M.; Taccagni, G.; Rabaiotti, E.; Viganò, R.; De Marzi, P.; Ferrari, D.; Mangili, G. (Milan)

15 Polymorphisms in Genes Coding for Cytokines, Mannose-Binding Lectin, Collagen Metabolism and Thrombophilia in Women with Cervical Insufficiency Sundtoft, I.; Uldbjerg, N. (Aarhus); Steffensen, R. (Aalborg); Sommer, S. (Horsens); Christiansen, O.B. (Aalborg/Copenhagen)

23 Waist Circumference as a Predictor of Failure of Sonographic Estimation of Fetal Birth Weight

Gultekin, I.B.; Altinboga, O.; Ozkaya, E.; Gultekin, S.; Mahmutoglu, S.; Kara, O.F.; Kucukozkan, T. (Ankara)

28 Complement Split Products C3a/C5a and Receptors: Are They Regulated by Circulating Angiotensin II Type 1 Receptor Autoantibody in Severe Preeclampsia? Ye, Y.; Kong, Y.; Zhang, Y. (Qingdao)

34 Is There a Correlation between the Number of Follicular Flushings, Oocyte/Embryo Quality and Pregnancy Rate in Assisted Reproductive Technology Cycles? Results from a Prospective Study

Neyens, S.; De Neubourg, D.; Peeraer, K.; De Jaegher, N.; Spiessens, C.; Debrock, S. (Leuven); De Loecker, P. (Leuven/Wilrijk); D’Hooghe, T.M. (Leuven)

41 Human Papillomavirus Positivity in Women Undergoing Intrauterine Insemination Has a Negative Effect on Pregnancy Rates

Depuydt, C.E.; Verstraete, L.; Berth, M.; Beert, J.; Bogers, J.-P.; Salembier, G.; Vereecken, A.J.; Bosmans, E. (Antwerp)

47 Biochemical, Histopathological and Immunohistochemical Evaluation of the Protective and Therapeutic Effects of Thymoquinone against Ischemia and Ischemia/Reperfusion Injury in the Rat Ovary

Mete Ural, Ü.; Bayoğlu Tekin, Y.; Şehitoğlu, İ.; Kalkan, Y.; Cumhur Cüre, M. (Rize)

54 Evaluation of Quantitative Fluorescence in situ Hybridization for Relative Measurement of Telomere Length in Placental Mesenchymal Core Cells

Toutain, J.; Prochazkova-Carlotti, M.; Horovitz, J.; Saura, R. (Bordeaux); Merlio, J.-P. (Bordeaux/Pessac); Chevret, E. (Bordeaux)

61 Physical Status and Variant Analysis of Human Papillomavirus 16 in Women from Shanghai

Guo, Y.; Hu, J.; Zhu, L.; Sun, J. (Shanghai); Xie, L. (Guangzhou); Kong, F.; Han, L.; Li, F. (Shanghai)
71 Assessment of Apoptotic Activity Dysregulation and Oxidative Stress in the Development of Epithelial Ovarian Cancer: A Case-Controlled Descriptive Analysis

Incebiyik, A.; Camuzcuoglu, H.; Vural, M.; Hilali, N.G.; Camuzcuoglu, A.; Seker, A. (Sanliurfa); Taskin, A.; Aksoy, N. (Istanbul)

78 Assessment of Protein:Creatinine Ratio versus 24-Hour Urine Protein in the Diagnosis of Preeclampsia

Valdés, E.; Sepúlveda-Martínez, Á.; Tong, A.; Castro, M.; Castro, D. (Santiago de Chile)

84 Association of Macrophage Migration Inhibitory Factor Polymorphisms with Gestational Diabetes Mellitus in Han Chinese Women

Li, C.; Qiao, B.; Qi, W.; Zhan, Y.; Ma, C.; Zhao, L.; Li, G. (Qingdao)

Novel Insights from Clinical Practice

90 Effects of $\mathrm{CO}_{2}$ Pneumoperitoneum on the Cognitive Function of Patients Undergoing Gynecologic Laparoscopy

Liu, L.-L.; Bao, N.; Lu, H.-W. (Shenyang)

Letter to the Editor

96 Serum Prolactin and CA-125 Levels as Biomarkers of Peritoneal Endometriosis

Bilibio, J.P. (Belém); Cunha-Filho, J.S.L. (Porto Alegre)

No. 2

Original Articles

97 Predictive Markers of Tubo-Ovarian Abscess in Pelvic Inflammatory Disease

Lee, S.W.; Rhim, C.C. (Anyang); Kim, J.H.; Lee, S.J.; Yoo, S.H.; Kim, S.Y.; Hwang, Y.B.; Shin, S.Y.; Yoon, J.H. (Asan)

105 Jewish Law, Scarcity of Sperm Donors and the Consequent Private Import of Sperm of Non-Jews by Israeli Women Bokek-Cohen, Y. (Ariel)

112 Aberrant Placental Villus Expression of miR-486-3p and miR-3074-5p in Recurrent Miscarriage Patients and Uterine Expression of These MicroRNAs during Early Pregnancy in Mice

Gu, Y. (Shanghai/Tianjin); Zhang, X.; Yang, Q. (Shanghai); Wang, J. (Tianjin); He, Y.; Sun, Z.; Zhang, H.; Wang, J. (Shanghai)

118 Advantages of Recombinant Follicle-Stimulating Hormone over Human Menopausal Gonadotropin in Intrauterine Insemination: A Randomized Clinical Trial in Polycystic Ovary Syndrome-Associated Infertility

Rashidi, M.; Najmi, Z.; Mobasseri, A. (Tehran)

124 Standardized Uptake Value on ${ }^{18}$ F-FDG PET/CT as a Prognostic Factor for Survival of Women with Malignant Uterine Tumors: A Meta-Analysis

Pan, Y.; Yao, Y.; Ma, Y. (Shanghai)

\section{KARGER}

E-Mail karger@karger.com www.karger.com
(C) 2016 S. Karger AG, Basel

Access to full text and tables of contents, including tentative ones for forthcoming issues: www.karger.com/goi_issues 
132 Outcomes of Transobturator Tape Surgery with Safyre $\mathrm{T}^{\circledR}$ Slings for Female Stress Urinary Incontinence after 96 Months of Follow-Up

Töz, E. (İzmir); Balsak, D. (Istanbul); Başoğul, N.;

Özdemir, A.A.; Okay, G.; Apaydın, N.; Özcan, A. (İzmir)

137 Predictive Value of Free $\beta$-hCG Multiple of the Median for Women with Preeclampsia

Liu, H.-Q.; Wang, Y.-H.; Wang, L.-L.; Hao, M. (Taiyuan)

148 Analysis of the Risk Factors for Aerobic Vaginitis: A Case-Control Study

Geng, N.; Wu, W.; Fan, A.; Han, C.; Wang, C.; Wang, Y.; Xue, F. (Tianjin)

155 Is Mechanical Bowel Preparation Necessary for Gynecologic Surgery? A Systematic Review and Meta-Analysis Zhang, J.; Xu, L.; Shi, G. (Chengdu)

162 High Expressions of Lgr5 and ALDH1 in Primary Epithelial Ovarian Cancer Correlate with Advanced Tumor Stage and Grade as well as Poor Prognosis of the Patients Sun, Y.; Jia, X.; Wu, X. (Shijiazhuang)

169 Management of Borderline Ovarian Tumors Based on Patient and Tumor Characteristics

Black, J.D.; Altwerger, G.H.; Ratner, E.; Lu, L.; Silasi, D.-A.; Azodi, M.; Santin, A.D.; Schwartz, P.E.; Rutherford, T.J. (New Haven, Conn.)

174 The Relationship between Retinol-Binding Protein 4 Concentrations and Gestational Diabetes Mellitus in Chinese Women

Du, M.; Wang, B.; Liang, Z.; Dong, M.; Chen, D. (Hangzhou)

181 Do Leukaemia Inhibitory Factor and Vascular Endothelial Growth Factor Have Any Roles in Intrauterine Device Mechanism of Action? An Experimental Rat Study

Cakmak, B. (Tokat); Ozalp, S.S.; Acikalin, M.F. (Eskisehir); Nacar, M.C. (Tokat)

Novel Insights from Clinical Practice

186 A Novel Molecular Cytogenetic Finding of Leiomyomatosis Peritonealis Disseminata

Wu, Y.-T.; Wu, Y.; Chen, S.-C.; Zhou, F.; Yang, C.-B.; Xie, Z.-W.; Xu, C.-M.; Jin, H.-M. (Hangzhou)

No. 3

Original Articles

193 Longitudinal Changes in Placental Magnetic Resonance Imaging Relaxation Parameter in Murine Pregnancy: Compartmental Analysis

Krishnamurthy, U. (Detroit, Mich.); Szalai, G. (Bethesda, Md./

Detroit, Mich.); Shen, Y. (Detroit, Mich.); Xu, Z. (Bethesda, Md./

Detroit, Mich.)); Yadav, B.K. (Detroit, Mich.); Tarca, A.L.;

Chaiworapongsa, T.; Hernandez-Andrade, E. (Bethesda, Md./Detroit, Mich.);

Than, N.G. (Bethesda, Md./Detroit, Mich./Budapest); Haacke, E.M

(Detroit, Mich.); Romero, R. (Bethesda, Md./Detroit, Mich.)/

Ann Arbor, Mich./East Lansing, Mich.); Neelavalli, J. (Detroit, Mich.)

202 Correlation between Maternal Characteristics during Early Pregnancy, Fetal Growth Rate and Newborn Weight in Healthy Pregnancies

Caradeux, J.; Serra, R.; Palmeiro, Y.; Correa, P.J.; Valenzuela, I.; Olguin, J.; Montenegro, L.; Nien, J.K.; Osorio, E.; Illanes, S. (Santiago)

207 The Development of a New Medical Device for Standardized Episiotomy: A Pre-Clinical Validation Study Mulder, F.; Piersma, D. (Amsterdam); Veersema, S. (Nieuwegein); van der Post, J.; Roovers, J.-P. (Amsterdam)

215 Patterns of First Recurrence in African American Patients with High Grade Epithelial Ovarian Carcinoma

Singh, S.; Armstrong, A.; Pettigrew, G.; Resnick, K. (Cleveland, Ohio.)
220 Predictors of Gestational Diabetes Mellitus in Chinese Women with Polycystic Ovary Syndrome: A Cross-Sectional Study Zhang, Y.; Jin, H.; Qin, Z.; Ma, J.; Zhao, H.; Zhang, L.; Chen, Z. (Jinan)

225 Protective Effect of Platelet Rich Plasma on Experimental Ischemia/Reperfusion Injury in Rat Ovary

Bakacak, M. (Kahramanmaras); Bostanci, M.S. (Sakarya); İnanc, F.; Yaylali, A.; Serin, S. (Kahramanmaras); Attar, R.; Yildirim, G.; Yildirim, O.K. (Istanbul)

232 Pregnancy and Neonatal Outcomes in Gestational Diabetes Treated with Regular Insulin or Fast-Acting Insulin Analogues You, J.Y.; Choi, S.-J.; Roh, C.-R.; Kim, J.-H.; Oh, S. (Seoul)

238 Mitochondrial DNA Haplogroup R Confers a Genetic Risk Factor for Intrauterine Adhesion in Han Women Population Zhang, J.; Zhu, L.; Huang, X.; Xu, P.; Chen, Z.; Huang, Q.; Zhang, X. (Hangzhou)

244 Hyaluronic Acid Binding Assay Is Highly Sensitive to Select Human Spermatozoa with Good Progressive Motility, Morphology, and Nuclear Maturity Rashki Ghaleno, L.; Rezazadeh Valojerdi, M.; Chehrazi, M.; Sahraneshin Samani, F.; Salman Yazdi, R. (Tehran)

251 Is It Possible to Perform Less Radical Surgery for Invasive Uterine Cervical Cancer?

Togami, S.; Kamio, M.; Kobayashi, H.; Douchi, T. (Kagoshima)

256 Quantitative Sonographic Differences in Mid-Urethra between Postmenopausal Women with and without Stress Urinary Incontinence

Olgan, S. (Antalya); Mantar, O.P. (Samsun); Okyay, R.E.; Gulekli, B. (Izmir)

262 Are Ultrasonographic Findings Suggestive of Ovarian Stromal Edema Associated with Ischemic Adnexal Torsion?

Yaakov, O.; Zohav, E.; Kapustian, V.; Gdalevich, M.; Volodarsky, M.; Anteby, E.Y.; Gemer, O. (Ashkelon)

267 SPAG9 May Be a Potential Prognostic Marker of Endometrial Hyperplasia and Grade 1 Endometrioid Adenocarcinoma Treated with Progestin

Li, C.; Bai, Y.; Yan, L.; Zhang, L.; Zhang, H.; Li, M.; Zhao, M.; Gao, Y.; Zhao, X. (Jinan)

275 The Pudendal Nerve and Its Branches in Relation to Richter's Procedure van der Walt, S.; Oettlé, A.C.; van Wijk, F.J. (Pretoria)

280 The Effect of Intrauterine Lidocaine and Rectal Indomethacin on Pain during Office Vaginoscopic Hysteroscopy: Randomized Double-Blind Controlled Study Senturk, M.B.; Guraslan, H.; Babaoğlu, B.; Yaşar, L.; Polat, M. (Istanbul)

Novel Insights from Clinical Practice

285 Vaginal Pessary for Uterine Repositioning during High-Intensity Focused Ultrasound Ablation of Uterine Leiomyomas

Klepac Pulanic, T.; Venkatesan, A.M.; Segars, J. (Bethesda, Md.); Sokka, S. (Cleveland, Ohio/Helsinki); Wood, B.J.; Stratton, P. (Bethesda, Md.)

\section{No. 4}

Review

289 Three-Dimensional Hysterosalpingo-Contrast-Sonography for the Assessment of Tubal Patency in Women with Infertility: A Systematic Review with Meta-Analysis Alcázar, J.L. (Pamplona); Martinez-Astorquiza Corral, T. (Bilbao); Orozco, R. (Murcia); Dominguez-Piriz, J. (Badajoz); Juez, L.; Errasti, T. (Pamplona) 
Original Articles

296 Analysis of Residual/Recurrent Disease and Its Risk Factors after Loop Electrosurgical Excision Procedure for High-Grade Cervical Intraepithelial Neoplasia

Wu, J.; Jia, Y.; Luo, M.; Duan, Z. (Chongqing)

302 The Effect of Patient Position during Mid-Urethral Sling Operations on the Postoperative Outcomes of Sling Success: A Randomized Clinical Study

Han, A. (Istanbul); Karaman, E.; Alkiş, İ. (Van); Ark, H.C.; Akça, A.; Numanoğlu, C.; Alptekin, B.B.; Tunca, A.F. (Istanbul)

308 Vitamin D Status Is Related to Oxidative Stress But Not High-Sensitive C-Reactive Protein in Women with Pre-Eclampsia

Pourghassem Gargari, B.; Pourteymour Fard Tabrizi, F.; Sadien, B.; Asghari Jafarabadi, M.; Farzadi, L. (Tabriz)

315 Obstetric Admissions to the Intensive Care Unit in a Tertiary Hospital

De Greve, M.; Van Mieghem, T.; Van Den Berghe, G.; Hanssens, M. (Leuven)

321 Diagnostic Delay of Endometriosis in the Netherlands Staal, A.H.J.; van der Zanden, M.; Nap, A.W. (Arnhem)

325 Reproductive Outcome of Infertile Patients with Fibroids Based on the Patient and Fibroid Characteristics; Optimal and Personalized Management

Tsuji, I.; Fujinami, N.; Kotani, Y.; Tobiume, T.; Aoki, M.; Murakami, K.; Kanto, A.; Takaya, H.; Ukita, M.; Shimaoka, M.; Nakai, H.; Suzuki, A.; Mandai, M. (Osaka)

333 Use of Oral Misoprostol for Cervical Priming before Hysteroscopy: A Randomized Comparison of Two Dosages Kesrouani, A.; Maalouf, S.; Mansour, F.; Attieh, E. (Beirut)

339 Pretreatment Factors Associated with Recurrence for Patients with Cervical Cancer International Federation of Gynecology and Obstetrics Stage IB1 Disease

Liu, S.-C.; Huang, E.-Y. (Kaohsiung); Hu, C.-F. (Puzi); Ou, Y.-C.;

ChangChien, C.-C.; Wang, C.-J.; Tsai, C.-C.; Fu, H.-C.; Wu, C.-H.; Lin, H. (Kaohsiung)

346 Long-Term Efficacy of Laparoscopic or Robotic Adenomyomectomy with or without Medical Treatment for Severely Symptomatic Adenomyosis Chong, G.O.; Lee, Y.H.; Hong, D.G.; Cho, Y.L.; Lee, Y.S. (Daegu)

353 Novel Nonsense Mutation in the NLRP7 Gene Associated with Recurrent Hydatidiform Mole Ito, Y.; Maehara, K. (Tokyo); Kaneki, E. (Fukuoka); Matsuoka, K.; Sugahara, N.; Miyata, T.; Kamura, H.; Yamaguchi, Y.; Kono, A.; Nakabayashi, K.; Migita, O. (Tokyo); Higashimoto, K.; Soejima, H. (Saga); Okamoto, A. (Tokyo); Nakamura, H.; Kimura, T. (Osaka); Wake, N. (Fukuoka); Taniguchi, T. (Osaka); Hata, K. (Tokyo)

359 Two-Dimensional Sonographic Evaluation of Endometrial Polyps - Parameters That Are Reassuring Goldberg, Y.; Lavie, O.; Mandel, R.; Kaufman, Y.; Segev, Y.; Auslender, R. (Haifa)

363 Utility of an Internal Retractor (EndoGrab) for the Management of the Vesicouterine Ligament during Laparoscopic Radical Hysterectomy

Kobayashi, E.; Kakuda, M.; Tanaka, Y.; Morimoto, A.; Egawa-Takata, T.; Matsuzaki, S.; Ueda, Y.; Yoshino, K.; Kimura, T. (Osaka)

367 Associations of Promoter Methylations and mRNA Expressions of MMP-2, MMP-7 and MMP-9 with Primary Fallopian Tube Carcinoma Ren, Y.; Zhou, Y.; Liu, M.; Zhang, S. (Huzhou)

Novel Insights from Clinical Practice

375 Ten-Year Experience with the Conservative Management of Abnormally Invasive, Residual Trophoblastic Disease. A Retrospective Case Series Promberger, R.; Ott, J.; Chalubinski, K.M. (Vienna)
381 Simple Technique for Transvaginal Aspiration of a Tubo-Ovarian Abscess

Lachiewicz, M.P.; Nair, N. (Atlanta, Ga.)

No. 5

Systematic Review

385 Primary Retroperitoneal Cystoadenocarcinoma: A Systematic Review

Pellegrino, B.; Sikokis, A.; Bersanelli, M.; Leonetti, A.; Leonardi, F. (Parma); Di Meglio, G. (Bolzano); Buti, S. (Parma)

Original Articles

394 Embryo Transfer with Controlled Injection Speed to Increase Pregnancy Rates: A Randomized Controlled Trial

Caanen, M.R.; van der Houwen, L.E.; Schats, R.; Vergouw, C.G.

(Amsterdam); de Leeuw, B. (Delft); Lambers, M.J.; Groeneveld, E.;

Lambalk, C.B.; Hompes, P.G. (Amsterdam)

405 Factors Affecting Adnexal Torsion Direction: A Retrospective Cohort Study

Krissi, H.; Hiersch, L.; Aviram, A.; Ashwal, E.; Goldschmit, C.; Peled, Y. (Tel Aviv)

411 Clinical Outcomes among Women with Mucinous Adenocarcinoma of the Ovary

Massad, L.S.; Gao, F.; Hagemann, I.; Powell, M. (St. Louis)

416 c-myc Gene Copy Number Variation in Cervical Exfoliated Cells Detected on Fluorescence in situ Hybridization for Cervical Cancer Screening

Zhao, W.-H.; Hao, M.; Cheng, X.; Yang, X.; Wang, Z.; Cheng, K.; Liu, F.; Bai, Y. (Taiyuan)

424 The Effects of Diabetes Mellitus on Ovarian Injury and Reserve: An Experimental Study Nayki, U.; Onk, D.; Balci, G.; Nayki, C.; Onk, A.; Gunay, M. (Erzincan)

430 CA125 and HE4: Measurement Tools for Ovarian Cancer Zhao, T.; Hu, W. (Hefei)

436 Assessment of an Alternative to the Uterine Vein for Venous Drainage in Human Uterine Transplantation: A Case Series Following Laparoscopic Hysterectomy

Arnolds, K.; Gomez, N.; Berry, A.; Stadtlander, K.; Watson, M.; Tzakis, A. (Weston, Fla.); Falcone, T. (Cleveland, Ohio); Zimberg, S. (Weston, Fla.)

442 Is Myomectomy Prior to Assisted Reproductive Technology Cost Effective in Women with Intramural Fibroids? Ojo-Carons, M. (New York, N.Y.); Mumford, S.L. (Rockville, Md.); Armstrong, A.Y.; DeCherney, A.H.; Devine, K. (Bethesda, Md.)

447 Comparison of Therapeutic Efficacies of Norethisterone, Tranexamic Acid and Levonorgestrel-Releasing Intrauterine System for the Treatment of Heavy Menstrual Bleeding: A Randomized Controlled Study

Kiseli, M.; Kayikcioglu, F.; Evliyaoglu, O.; Haberal, A. (Ankara)

454 A Novel System for Single-Port Laparoscopic Surgery: Preliminary Experience

Freschi, L. (Pisa); Pluchino, N. (Geneva); Angioni, S. (Cagliari); Simi, G.; Ruggiero, M.; Cela, V. (Pisa)

461 Enhanced Recovery after Surgery Protocol in Abdominal Hysterectomies for Malignant versus Benign Disease Wijk, L.; Franzén, K.; Ljungqvist, O.; Nilsson, K. (Örebro)

468 Serum Levels of 25-Hydroxyvitamin D and Time to Natural Pregnancy Somigliana, E.; Paffoni, A.; Lattuada, D.; Colciaghi, B.; Filippi, F.; La Vecchia, I.; Tirelli, A.; Baffero, G.M.; Persico, N.; Viganò, P.; Bolis, G.; Fedele, L. (Milan) 
Novel Insights from Clinical Practice

472 Influences of Pregnancy on Different Genetic Subtypes of Non-Dystrophic Myotonia and Periodic Paralysis

Rudnik-Schöneborn, S. (Aachen/Innsbruck); Witsch-Baumgartner, M. (Innsbruck); Zerres, K. (Aachen)

477 Successful Pregnancy after Improving Insulin Resistance with the Glucagon-Like Peptide-1 Analogue in a Woman with Polycystic Ovary Syndrome: A Case Report and Review of the Literature

Yang, Q.; Wang, F. (Guangzhou)

\section{No. 6}

Narrative Review

481 Management of Abnormal Placenta Implantation with Methotrexate: A Review of Published Data

Farasatinasab, M. (Tehran); Moghaddas, A. (Isfahan); Dashti-Khadivaki, S.; Raoofi, Z.; Nasiripour, S. (Tehran)

Original Articles

497 Use of TachoSil ${ }^{\circledR}$ to Prevent Symptomatic Lymphocele after an Aggressive Tumor Debulking with Lymphadenectomy for Advanced Stage Ovarian Cancer. A Pilot Study

Minig, L. (Valencia); Patrono, M.G. (Buenos Aires); Cárdenas-Rebollo, J.M.; Martin Marfil, P.; Rodriguez-Tabares, V. (Madrid); Chuang, L. (New York)

504 Predictors of Paracentesis in Women with Severe Ovarian Hyperstimulation Syndrome: A Retrospective Cohort Study Nouri, K.; Ott, J.; Lenart, C.; Walch, K.; Promberger, R. (Vienna); Tempfer, C.B. (Bochum)

512 Prospective Evaluation of a Panel of Plasma Cytokines and Chemokines as Potential Markers of Pelvic Endometriosis in Symptomatic Women

Rocha, A.L.; Vieira, E.L.; Maia, L.M.; Teixeira, A.L.; Reis, F.M. (Belo Horizonte)

518 Assessment of Cervicovaginal Cancer Antigen 125 Levels: A Preliminary Study for Endometrial Cancer Screening Calis, P.; Yuce, K.; Basaran, D.; Salman, C. (Ankara)
523 The Use of a Novel Optical Algorithm in the Diagnosis of Cervical Pre-Invasive Pathology - A Preliminary Proof of Principal Study

Eitan, R.; Krissi, H.; Peled, Y.; Braslavsky, D.; Binyamin, L.; Peretz-Davidi, Y. (Petach Tikva/Tel Aviv); Seadia, O.; Landesman, I. (Netanya)

529 Association of Vasculogenic Mimicry Formation and CD133 Expression with Poor Prognosis in Ovarian Cancer Liang, J.; Yang, B.; Cao, Q.; Wu, X. (Shijiazhuang)

537 The Effectiveness and Acceptability of Pipelle Endometrial Sampling versus Classical Dilatation and Curettage: A Three-Year Observational Study Rezk, M.; Sayyed, T.; Dawood, R. (Menoufia)

543 Increased Heme Oxygenase-1 and Nuclear Factor Erythroid 2-Related Factor-2 in the Placenta Have a Cooperative Action on Preeclampsia

Li, J.; Zhou, J. (Jinan/Qingdao); Ye, Y. (Qingdao); Liu, Q. (Jinan/Qingdao); Wang, X. (Shanghai); Zhang, N. (Qingdao); Wang, X. (Jinan)

552 Clinical Outcomes after Selective Fetal Reduction of Complicated Monochorionic Twins with Radiofrequency Ablation and Bipolar Cord Coagulation Peng, R.; Xie, H.-N.; Lin, M.-F.; Yang, J.-B.; Zhou, Y.; Chen, H.-Q.; Zhu, Y.-X. (Guangzhou)

Novel Insights from Clinical Practice

559 Hemoperitoneum Following Sexual Intercourse in a Woman with Deep Infiltrating Endometriosis Buggio, L.; Aimi, G.; Vercellini, P. (Milan)

563 Optimizing the Histological Diagnosis of Adenomyosis Using in vitro Three-Dimensional Ultrasonography

Van den Bosch, T. (Leuven/Tienen); Votino, A. (Leuven/Brussels); Cornelis, A.; Vandermeulen, L. (Tienen); Van Pachterbeke, C. (Brussels); Van Schoubroeck, D.; Timmerman, D. (Leuven)

Letter to the Editor

568 Hysteroscopy or Not before Intracytoplasmic Sperm Injection: How Significant Is the Difference? El-Toukhy, T.; El Tokhy, O. (London)

569 Acknowledgement to Reviewers 